\title{
ANALYSIS OF THE ECONOMIC TERMS OF THE INTERNET MEDIA IN THE SLOVAK REPUBLIC
}

\author{
Marcel Lincényi ${ }^{1}$ \\ Michal Fabuš $\breve{2}^{2}$
}

DOI: https://doi.org/10.31410/ITEMA.S.P.2019.107

\begin{abstract}
The main objective of presented research study is to analyse the development trends of selected Slovak Internet media in the monitored period 2008-2017. The research has confirmed that the media on the Internet is the fastest growing media market in the Slovak Republic in recent years, which is characterized not only by a noticeable increase in Internet media traffic, but also by a clear trend of ad growth in this sector. Research has shown, among other things, that media traffic on the Internet has quadrupled over the next 10 years, with advertising volumes in the online advertising media being up almost five times over.
\end{abstract}

Keywords: Trends, Analysis, Internet Advertising, Internet Media Traffic.

\section{INTRODUCTION}

$\mathrm{W}^{\mathrm{c}}$ e can analyse and evaluate the development trends of the Internet media market based on Internet media traffic and the volume of Internet advertising. The Slovak Internet is still growing. It has become the part of the life of not only the younger generation but of almost the entire population.

The Internet can transfer information and in such forms as audio and video recordings and the quality where traditional media fail (V. Vavrečka, J. Mezuláník, 2015). The Internet has significantly influenced the development in the world and is now regarded as the main communication channel - an information medium, which triggered massive changes in the area of trade, marketing and communication (I. Bulanda et al. 2018).

The phenomenon of social networks has made it an important medium for modern communication. It is fast, cheap and provides almost instant feedback. Although the Internet is a symbol of freedom, the paradox is that digital agencies know almost everything about the user. This is extremely advantageous for the advertiser because he pays for a defined target group or number of visits.

Nowadays, it is also possible to target the communication campaign strictly regional, or just to a very narrow target group, and the success of the campaign will really be only about the quality of the message. The only disadvantage of measuring the Internet is that most of the data are declared by the respondent and it is not possible to verify them - mainly the socio-demographic data (age, status, income, employment). The location of the connection, the number of unique visits, and the location are accurate. ${ }^{3}$

$1 \quad$ Department of Economics and Finance, Economics and Management Institute, School of Economics and Management of Public Administration in Bratislava, Slovakia

2 Department of Economics and Finance, Economics and Management Institute, School of Economics and Management of Public Administration in Bratislava, Slovakia

3 Lipták, R. Analýza mediálneho trhu v Slovenskej republike [online]. c2014 [cit. 2016-02-16]. Available at: $<$ http://webcache.googleusercontent.com/search?q=cache:YOvG2PMG15AJ:www.nsrr.sk/ 
Since when data on Slovak households have been available (2006), the proportion of households connected to the Internet has tripled until 2017- from 26.6\% in 2006 (Vlačuha et al., 2012) to $81.3 \%$ in 2017 (Vlačuha et al., 2017). The highest increase was recorded in 2007 (19.5\%), while the high growth continued in 2008 (12,2\%). Between 2009 and 2012, the proportion of households connected to the Internet grew from 3 to 5\%, (Vlačuha et al., 2012) and from 2013 to the present it is approximately $1 \%$ increase in connected households per year. (Vlačuha et al. 2017). Most frequently, over the last 3 months, the Internet was used by respondents aged 35-44 (95.3\%), 16-24 (95\%), 25-34 (93.7\%), from the entire population aged 16-74. 54 (84.4\%), with the least respondents aged 55-64 (65.1\%) and respondents aged 65-74 (36.6\%). (Vlačuha et al. 2017).

\section{METHODOLOGY}

The main objective of the presented research study was to analyse the development trends of the selected Slovak Internet media in the monitored period 2008-2017.

The side research objective of the empirical part was to analyse the development of the media audience size of selected Internet media in the Slovak republic in 2008-2017 based on Internet media traffic.

The next side research objective was to analyse the development of the volume on Internet advertising in the Slovak republic in 2008-2017.

In the case of further planning and research, we prioritized the concept of research questions. We identified one major research question (VO) that we have developed on two other specific research questions:

- The main research question: What were development trends of the market of selected Slovak Internet media in the Slovak Republic like during the monitored period 2008-2017?

- Specific question 1: What was development of website traffic in the monitored period 2008-2017 like?

We expected more than double increase of website traffic in the Slovak Republic in 2017 compared to 2018. We based on results of the Statistical Office of the Slovak Republic, which have found out that from 2006 to 2017 the ratio of households connected to the Internet increased up to three times. (Vlačuha et al. 2017).

- Specific question 2: What was the development of the advertising volume in selected Internet media in the Slovak republic like during the monitored period 2008-2017?

We expected more than triple increase of advertising volume in Internet in $2017 \mathrm{com}-$ pared to 2018. This statement was set not only on development trends of connected households on the Internet, but also on the basis of development trends of volume advertising of nationwide newspapers, which almost tripled in the years 2000 to 2014. (Lincényi, Fabuš 2017).

\subsection{Research methods}

We used economic analysis and comparative analysis in a research. As the part of the economic analysis, we analysed the Internet advertising monitoring of all monitored Internet advertising media and we also analysed real Internet users. "Analysis of advertising revenues, so-called

download.php\%3FFNAME\%3D1418718194.upl\%26ANAME\%3DAnal\%25C3\%25BDza\%2Bslovens keho $\% 2$ Bmedialneho $\% 2$ Btrhu.pdf $+\& \mathrm{~cd}=1 \&$ hl $=$ sk \&ct=clnk\&gl=sk $>$ 
advertising monitoring has quantitative aspects. The volume of advertising is one of the essential indicators according to which the concentration in the media market (increasing the market share of media operators) is assessed." (Trampota, 2010, pp. 46-47)

After data collection, we subjected the data to the process of verification, selection and classification. This was followed by a comparative analysis, where we compared the individual data across the monitored period between 2008 and 2017. We processed the data into graphs for a clearer presentation of comparative analysis results.

\subsection{Research material:}

Although the Internet is very dynamic environment, the Internet media market in the Slovakia has been stable over the past few years. This is proven by the fact that over recent years the same web portals are still in place in the chart of top-twenty, only their order sometimes changes.

To analyse the volume of Internet advertising in the Slovakia in 2008-2017, we will use the data of the Interactive Advertising Bureau Slovakia (IAB Slovakia). IAB Slovakia - Association of the Internet Media is the biggest association on the Slovak digital market. Currently it has 40 members, including the biggest Slovak publishers, media agencies and other important players active in online advertising. IAB operates AIMmonitor, which is a comprehensive, independent audited visit ranking of the Slovak online media. ${ }^{4}$

We conducted an analysis of the development of Internet media traffic in Slovakia based on AIMmonitor results.

AIMmonitor is the measurement tool of the audience of the online advertising media. Data from AIMmonitor are officially accepted data (single currency) by media agencies, advertising agencies and sponsors. AIMmonitor offers data about visits of the Internet media and socio-demographic profile of the online audience. Access to the data is for the purpose of planning, purchase and evaluation of the advertising campaigns of the Internet media in Slovakia. This project was officially launched in January 2007. The sponsor of the research is IAB Slovakia and the project is executed by Gemius Slovakia. AIM monitor is executed by the Gemius AudienceTm system, which consists of these main parts: Gemius Traffic measurement tool, which enables the monitoring of the usage of a webpage, assessing the reading scripts from the source code of the webpage. Pop-up panel, which secures the collection of socio-demographic data about the web page visitors. ${ }^{5}$

We analysed the development of Internet media traffic according to real user data. We compared the individual years due to spatial reasons according to the data in January, but the basic rule of the research method was to compare what can be comparable. The author is conscious that there have been minor deviations, either in decline or increment, in the conversion of the Internet media market share of each month during the year, but these have not been so significant since in one year the order of these Internet media has not changed.

4 IAB Slovakia. 2018. About Us. [online]. 2018 [8.10.2018]. Available at: https://www.iabslovakia.sk/us/

5 IAB Slovakia. 2019. AIMmonitor. [online]. 2018 [2.1.2019]. Available at:

https://www.iabslovakia.sk/aimmonitor-2/ 


\section{ANALYSIS}

\subsection{Analysis of the development of the volume of Internet advertising in the Slovak Republic}

In 2017, the cost of Internet advertising in Slovakia reached almost 118 million Euro. In terms of spending on individual formats, native advertising grew the most, reaching a quadruple of 2016 spending. Among the media, video grew by $39 \%$ compared to 2016. The growth of programmatic advertising sales by $62 \%$ is due to the media work - possibly due to automated purchase of their media space. Banner advertising overall recorded a minimal increase (of 0,4 $\%$ ) compared to 2016. Growth has been reported by the type of "classifieds and directories" by $8 \%$. The company recorded a significant increase in mobile advertising for the entire market and in the membership base (for members 7.5 times 2016) as well. Currently, mobile advertising accounts for $37 \%$ of total spending. In 2017, a media space worth was more than 9 mil. Euros. This purchase method is particularly attractive for video ads. ${ }^{6}$

In 2016, spending on online advertising exceeded 112 million $€$. According to the declared income of the members of the Internet advertising association IAB Slovakia and the classified AdEx commission estimate, expenditures on Internet advertising grew year-on-year by $23.2 \%$. Since 2012, this has been the highest year-on-year growth rate. In absolute terms, banner advertising is at the forefront with $28.4 \%$ growth. The year-on-year growth of programmatic advertising, video, and mobile advertising is under the sign of its year-on-year growth. This trend is also reflected in member media declarations: programmatic recorded $47 \%$ growth, mobile display advertising $46 \%$ growth and video advertising $29 \%$ growth compared to 2015 . In total, however, these three categories in 2016 account for only $30 \%$ of the banner advertising declared by IAB members. Searching maintains a solid position, but its overall share of advertising spending has fallen slightly compared to the previous year.

The highest percentage of the year-on-year increase was recorded in the Other item, where several forms of advertising are included, but they do not show high numbers alone in absolute terms. Among these formats, most spending is directed to native advertising, PR articles, and affiliate marketing. Native advertising achieved $90 \%$ growth among member media compared to $2015 .{ }^{7}$

Income from Internet advertising on the Slovak online market jumped by $20.5 \%$ in 2015. In 2015, Slovak advertisers spent more than 91 million $€$ on Slovak and multinational Internet media. Compared to 2014, this is a $20.5 \%$ increase. Revenues are made up of declared reported revenues of IAB Slovakia member media and a qualified estimate of non-member media revenues as well as multinational companies operating on the Slovak online market. IAB Slovakia members declare revenues from online on a half-year basis. We appreciate the return of the gradual increase in percentage growth in year-on-year comparisons, as revenues from online growth increased between 2013 and 2014, but by almost 3\% less than in the previous year-onyear comparison. ${ }^{8}$

$6 \quad$ PZ. 2018. Výdavky do internetovej reklamy v roku 2017 narástli. Najviac zadávatelia investovali do nativnej reklamy. [online]. 2018 [8.10.2018]. Available at: https://strategie.hnonline.sk/marketing/1721790-vydavky-do-internetovej-reklamy-v-roku-2017-narastli-najviac-zadavatelia-investovali-do-nativnej-reklamy IAB. 2017. V roku 2016 výdavky do internetovej reklamy presiahli hranicu 112 miliónov eur. [online]. 2017 [8.10.2018]. Available at: https://www.iabslovakia.sk/tlacove-centrum/v-roku-2016-vydavky-internetovejreklamy-presiahli-hranicu-112-milionov-eur/

$8 \quad$ IAB. 2016. Príjmy z internetovej reklamy na slovenskom online trhu poskočili o 20,5 \%. [online]. 2016 [8.10.2018]. 
Internet advertising in 2014, according to IAB Slovakia, increased by $14.7 \%$ compared to 2013. In absolute terms, the volume of advertising in 2014 reached more than 75.5 mil. $€$. Thus, the volume growth slowed down from an aggregate point of view (2013/2012 17.5\%). In absolute terms, growth is almost 9.7 million. $€{ }^{9}$

Online advertising spending in Slovakia has increased by 17.3 per cent in 2013, according to the IAB's Internet Media Association, which was the third-highest jump in other European countries. Expenditure grew faster in Russia $(+26.8 \%)$ and Turkey $(+24.3 \%)$. The value of the Slovak online advertising market IAB Slovakia estimated at 65.8 million $€$ in the 2013 report, excluding agency commissions and bonuses. This volume also included estimates of revenue for actors like Facebook and Google, which do not provide local data. The year-on-year increase was 18\%. According to ZenithOptimedia media network estimates, real Internet advertising spending in Slovakia reached 45 million $€$. According to them, the year-on-year increase was 28.6 percent. $^{10}$

In 2012 total Internet advertising spending in Slovakia amounted to 56,022,793 mil. $€$, which consists of display $(21,330,188)$, classifieds a Directories $(12,446,982)$, paid-for search $(20,231,973)$, and others. ${ }^{11}$

In 2011 total spending on Internet advertising in Slovakia was in the amount of 45175847 mil. $€$, which consists of display $(20,793,003)$, classifieds a Directories $(7,456,469)$, paid-for search $(13,113,166)$, sponsorship $(950,837)$, e-mail $(514,967)$, slotting fees $(168,368)$, rich media $(1,406,264)$, and lead generation $(772,773) .^{12}$

In 2010 total Internet advertising spending in Slovakia amounted to 25,086,605 mil. $€$, which consists of display $(13,105,787)$, classifieds a Directories $(4,961,665)$, paid-for search $(3,973,87)$, sponsorship $(736,806)$, e-mail $(751,963)$, slotting fees $(114,992)$, rich media $(1,119,134)$, and lead generation $(322,371) .^{13}$

In 2009 total spending on Internet advertising in Slovakia was in the amount of 23,291,985 mil. $€$, which consists of display $(12,112,774)$, classifieds a Directories $(5,167,190)$, paid-for search $(3,757,636)$, sponsorship $(445,345)$, e-mail $(608,095)$, slotting fees $(150,473)$, rich media $(990,663)$, and lead generation $(59,809) .{ }^{14}$

Available at: https://www.iabslovakia.sk/tlacove-centrum/prijmy-z-internetovej-reklamy-na-slovenskom-online-trhu-poskocili-o-205/

$9 \quad$ IAB. 2015. Objemy reklamy na Slovensku v roku 2014. [online]. 2015 [8.10.2018].

Available at: https://www.iabslovakia.sk/tlacove-centrum/objemy-reklamy-slovensko-tlacova-sprava/

10 CWITKOVICS, Tomáš. 2014. Rast výdavkov do online reklamy bol vlani na Slovensku tretí najvyšší v Európe. [online]. 2014 [8.10.2018].

Available at: https://medialne.etrend.sk/internet/rast-vydavkov-do-online-reklamy-bol-vlani-na-slovensku-treti-najvyssi-v-europe.html

11 IAB Slovakia. 2018. Objem internetovej reklamy (SK). [online]. 2018 [8.10.2018]. Available at: https://www.iabslovakia.sk/vydavky-do-reklamy/objemy-internetovej-reklamy-sk-2017/

12 IAB Slovakia. 2018. Objem internetovej reklamy (SK). [online]. 2018 [8.10.2018]. Available at: https://www.iabslovakia.sk/vydavky-do-reklamy/objemy-internetovej-reklamy-sk-2017/

13 IAB Slovakia. 2018. Objem internetovej reklamy (SK). [online]. 2018 [8.10.2018]. Available at: https://www.iabslovakia.sk/vydavky-do-reklamy/objemy-internetovej-reklamy-sk-2017/

14 IAB Slovakia. 2018. Objem internetovej reklamy (SK). [online]. 2018 [8.10.2018]. Available at: https://www.iabslovakia.sk/vydavky-do-reklamy/objemy-internetovej-reklamy-sk-2017/ 
In 2008 total Internet advertising spending in Slovakia amounted to 24,627,461 mil. $€$, which consists of display $(14,176,425)$, classifieds a Directories $(4,753,933)$, paid-for search $(4,026,223)$, sponsorship $(504,845)$, e-mail $(733,685)$, slotting fees $(0)$, rich media $(389,199)$ and lead generation $(43,151){ }^{15}$

We have tried to show the concrete evolution of Internet advertising investments, expressed in accurate figures in euros, for a more precise view of developments. See figure no. 1.

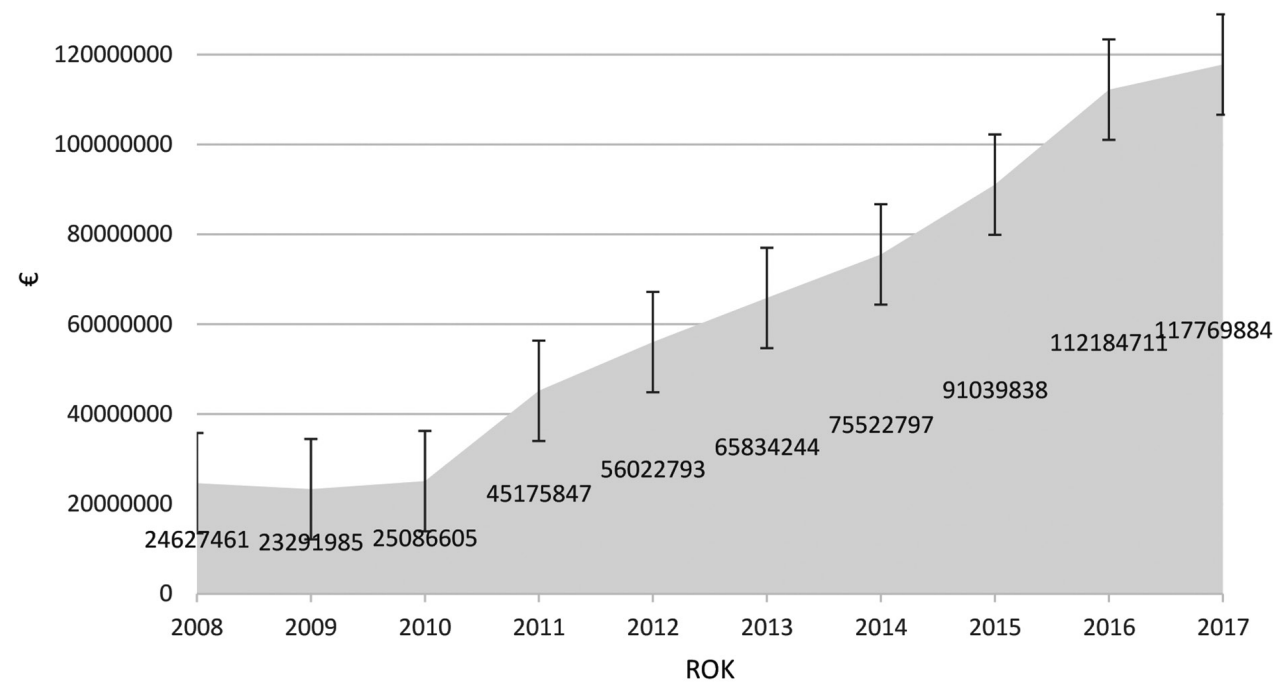

Figure 1: Analysis of the development

of the total volume of Internet advertising $(€)$ in 2008 - 2017

Source: Processed from the results of the IAB Slovakia

\subsection{Analysis of Internet media traffic development in the Slovak Republic}

In January of 2017, AIMmonitor estimated 44001407 real Internet users for the monitored online media. Of this, the greatest amount of real Internet users had: azet.sk (2799976), zoznam. sk (2444011), sme.sk (2262691), aktuality.sk (2129825), atlas.sk (1867208), cas.sk (1849794), heureka.sk (1813390), bazos.sk (1609764), topky.sk (1603171), pluska.sk (1552757).

In January of 2016, AIMmonitor estimated 40515656 real Internet users for the monitored online media. Of this, the greatest amount of real Internet users had: azet.sk (2830281), zoznam.sk (2471274), sme.sk (2290470), aktuality.sk (2087634), cas.sk (1996733), atlas.sk (1926375), topky. sk (1677576), heureka.sk (1654680), pravda.sk (1604287), pluska.sk (1488670).

In January of 2015, AIMmonitor estimated 34360924 real Internet users for the monitored online media. Of this, the greatest amount of real Internet users had: azet.sk (2665446), zoznam.sk (2354199), sme.sk (2118123), aktuality.sk (2079434), cas.sk (1833787), atlas.sk (1753452), topky. sk (1616898), pravda.sk (1389159), heureka.sk (1364720), pluska.sk (1064119).

In January of 2014, AIMmonitor estimated 30255711 real Internet users for the monitored online media. Of this, the greatest amount of real Internet users had: azet.sk (2464813), zoznam.sk (2327346), sme.sk (2044255), aktuality.sk (1836445), cas.sk (1816727), atlas.sk (1771945), topky. sk (1650441), pravda.sk (1369282), heureka.sk (1340724), pluska.sk (932020).

15 IAB Slovakia. 2018. Objem internetovej reklamy (SK). [online]. 2018 [8.10.2018]. Available at: https://www.iabslovakia.sk/vydavky-do-reklamy/objemy-internetovej-reklamy-sk-2017/ 
In January of 2013, AIMmonitor estimated 28198046 real Internet users for the monitored online media. Of this, the greatest amount of real Internet users had: azet.sk (2239822), zoznam.sk (2163349), sme.sk (1997242), aktuality.sk (1811100), atlas.sk (1784175), topky.sk (1516419), cas. sk (1388014), pravda.sk (1253475), heureka.sk (1176065), centrum.sk (801748).

In January of 2012, AIMmonitor estimated 22871084 real Internet users for the monitored online media. Of this, the greatest amount of real Internet users had: azet.sk (1827188), zoznam. sk (1802722), sme.sk (1620139), atlas.sk (1460265). aktuality.sk (1362534), topky.sk (1236412), cas.sk (1038064), pravda.sk (976726), centrum.sk (840738), heureka.sk (787201).

In January of 2011, AIMmonitor estimated 19927760 real Internet users for the monitored online media. Of this, the greatest amount of real Internet users had: azet.sk (1791791), zoznam.sk (1749549), sme.sk (1506503), atlas.sk (1391302), topky.sk (1038870), aktuality.sk (897684), pravda.sk (867745), cas.sk (840360), centrum.sk (814374), markiza.sk (683703), tvnoviny.sk (557736)

In January of 2010, AIMmonitor estimated 16763205 real Internet users for the monitored online media. Of this, the greatest amount of real Internet users had: azet.sk (1742961), zoznam. sk (1585418), sme.sk (1373440), atlas.sk (1309864), topky.sk (928841), aktuality.sk (831254), centrum.sk (809122), pravda.sk (693769), cas.sk (590151), markiza.sk (565333).

In January of 2009, AIMmonitor estimated 13566472 real Internet users for the monitored online media. Of this, the greatest amount of real Internet users had: azet.sk (1518960), zoznam. sk (1470046), atlas.sk (1227663), sme.sk (1156486), topky.sk (871912), centrum.sk (765202), aktuality.sk (752985), pravda.sk (566515), markiza.sk (511792), cas.sk (505441).

In January of 2008, AIMmonitor estimated 10279495 real Internet users for the monitored online media. Of this, the greatest amount of real Internet users had: zoznam.sk (1460097), azet.sk (1294699), atlas.sk (1149290), sme.sk (975949), topky.sk (928026), centrum.sk (719827), aktuality.sk (562071), markiza.sk (500747), pravda.sk (428693), profesia.sk (393928).

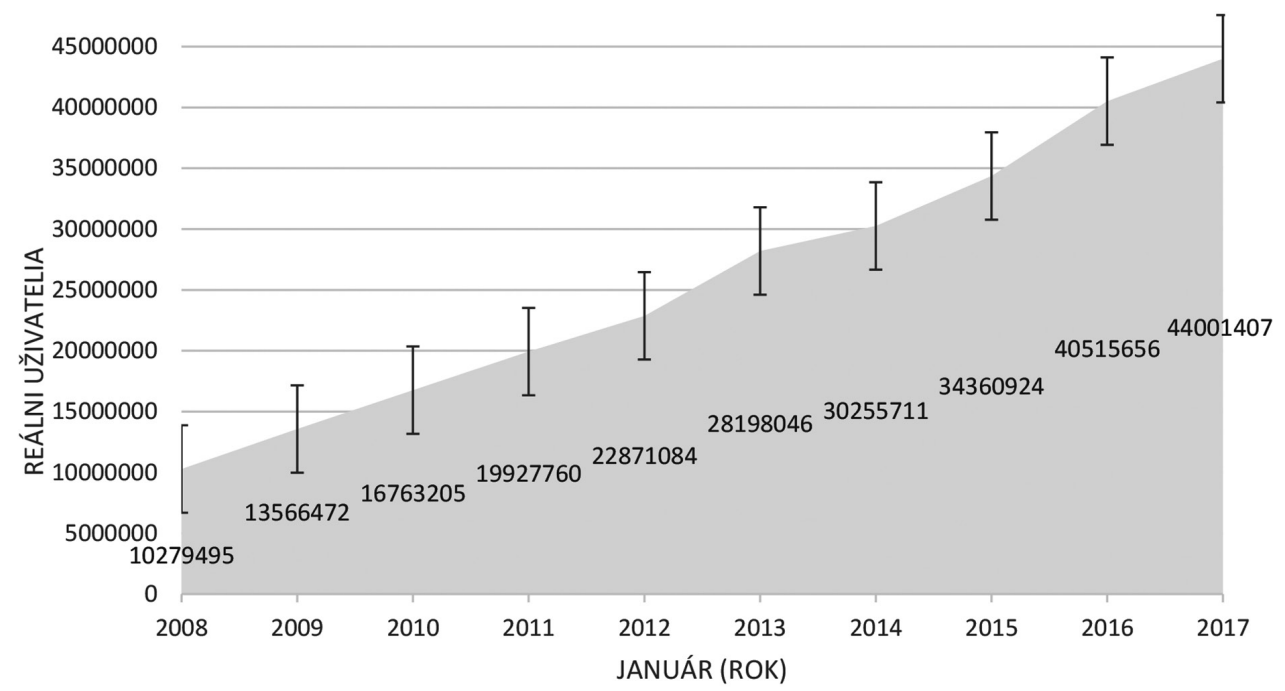

Figure 2: Analysis of the development of estimated actual Internet users (month January) in 2008-2017

Source: Processed from the results of the AIMmonitor 


\section{RESULTS AND DISCUSSION}

As part of the first specific research question, we anticipated more than double increase in Internet media traffic in the Slovak Republic in 2017 compared to 2008, based on the results of the Statistical Office of the Slovak Republic, according to which the household ratio connected to the Internet grew up to three times. (Vlačuha et al. 2017). This assumption was confirmed. However, the analysis showed that the increase was far higher than the expected double of traffic, as the actual amount of Internet users in January 2008 (January - 10,279,495) increased by four times by 2017 (January - 44,001,407). After examining the visits of the Internet media in Slovakia, there is a clear trend that has been increasing over the past 10 years, as the number of Internet users has not fallen year on year in a single year. The highest increase in Internet users was recorded in the period 2015-2017, when the number of Internet users grew by almost a third compared to the January 2014. In January 2016, up to 6,154,732 Internet users were added compared to January in the previous year. The year-on-year increase in Internet users was so strong that even in January, the number of real users did not drop below 2,000,000 users compared to the previous period. When calculating the share of real Internet users, it can be stated that the Internet media market has been stable in recent years, because since 2010 the order of the first 3 places has not changed: 1. azet.sk, 2. zoznam.sk, 3. atlas.sk. In 2009 the leader of Internet media became azet.sk, which moved on zoznam.sk to the second place where it stayed until 2017. In 2008-2009 at the third place was atlas.sk, which in 2010 was replaced by sme.sk, which was in this position until 2017.

As part of the second specific research question, we expected more than threefold increase in the volume of Internet advertising in 2017 compared to 2008, with our opinion based on the trends of connected households on the Internet, but also on the results of research into the development of the volume of advertising of the nationwide newspapers almost tripled between 2000 and 2014. (Lincényi, 2017). This claim was also confirmed. However, the analysis showed that the increase was far higher than the expected double, as the total volume of online advertising in 2008 ( $€ 24,627,461)$ increased almost fivefold by 2017 (117,769,884 €). The highest increase in advertising volume compared to the previous year was observed in $2016(21,144,873 €)$, and then in $2011(20,089,242 €)$.

It is very interesting that the increase in advertising volume compared to the previous year in the period between 2011 and 2016 was so strong that it never fell below 9 million euros. The stagnation of the upward trend can be seen in 2009, 2010 and 2017. The volume of Internet advertising on the Slovak market in the period under review decreased only once in $2009(23,291,985 €)$, when the total volume of Internet advertising was lower than in the previous year $(24,627,461 €)$ and the subsequent stagnation trend in $2010(25,086,605 €)$. This decline and stagnation can be explained by the effects of the global economic crisis.

\section{CONCLUSION}

Based on the development analysis of the volume of advertising in selected national Internet media in the Slovak Republic in 2008 to 2017, the following conclusion can be drawn:

In the analysed period (2008-2017), there was a noticeable upward trend in Internet media traffic in Slovakia, which increased fourfold from 2008 (January - 10,279,495) in the same period to 2017 (January - 44,001,407), while the number of Internet users has not fallen year-on-year. In 
the analysis of calculations of the share of real Internet users it can be further stated that this market of Internet media has been stable in recent years; since 2010 the order of the top 3 places has not changed (1. azet.sk, 2. zoznam.sk, 3. atlas.sk). While the market share of Internet media in the months during the year was smaller, there were minor deviations, either in decline or increase, but in one year, the order of these online media has not changed.

In addition, a clear upward trend in Internet advertising can be observed over the period under review, rising almost five times from $2008(24,627,461 €)$ to $2017(117,769,884 €)$. The impacts of the global economic crisis were reflected in the Slovak Internet market until 2009, when the total volume of Internet advertising $(23,291,985 €)$ was lower than in $2008(24,627,461 €)$ and the subsequent stagnation trend in $2010(25,086,605 €)$.

\section{REFERENCES}

Bulanda. I. et al. (2018). Slovak consumers from generation Y and their shopping behavior on discount portals. In International Scientific Days 2018: "Towards Productive, Sustainable and Resilient Global Agriculture and Food Systems." Conference Proceedings, Nitra May 16-17, 2018. Praha: Wolters Kluwer, 2018. ISBN 978-80-7598-180-6, p. 275-287.

Czwitkovics, T. (2014). Rast výdavkov do online reklamy bol vlani na Slovensku tretí najvyšší v Európe. [online]. 2014 [8.10.2018]. Available at: https://medialne.etrend.sk/Internet/rastvydavkov-do-online-reklamy-bol-vlani-na-slovensku-treti-najvyssi-v-europe.html

IAB Slovakia. (2018). About Us. [online]. 2018 [8.10.2018]. Available at: https://www.iabslovakia.sk/us/

IAB Slovakia. (2019). AIMmonitor. [online]. 2018 [2.1.2019]. Available at: https://www.iabslovakia.sk/aimmonitor-2/

IAB. (2017). V roku 2016 výdavky do Internetovej reklamy presiahli hranicu 112 miliónov eur. [online]. 2017 [8.10.2018]. Available at: https://www.iabslovakia.sk/tlacove-centrum/v-roku-2016-vydavky-Internetovej-reklamy-presiahli-hranicu-112-milionov-eur/

IAB. (2016). Príjmy z Internetovej reklamy na slovenskom online trhu poskočili o 20,5\%. [online]. 2016 [8.10.2018]. Available at: https://www.iabslovakia.sk/tlacove-centrum/prijmy-z-Internetovej-reklamy-na-slovenskom-online-trhu-poskocili-o-205/

IAB. (2015). Objemy reklamy na Slovensku v roku 2014. [online]. 2015 [8.10.2018]. Available at: https://www.iabslovakia.sk/tlacove-centrum/objemy-reklamy-slovensko-tlacova-sprava/

IAB Slovakia. (2018). Objem Internetovej reklamy (SK). [online]. 2018 [8.10.2018]. Available at: https://www.iabslovakia.sk/vydavky-do-reklamy/objemy-Internetovej-reklamy-sk-2017/

Lincényi, M. \& Fabuš, M. (2017). Economic trends of business actors on daily newspaper market: Case of the Slovak Republic. Entrepreneurship and Sustainability issues. Volume 5, Number 1, ISSN 2345-0282. DOI: http://doi.org/10.9770/jesi.2017.5.1

Lipták, R. Analýza mediálneho trhu v Slovenskej republike [online]. c2014 [cit. 2016-02-16]. Available at: $<$ http://webcache.googleusercontent.com/search?q=cache:YOvG2PMG15AJ:www.nsrr.sk/ download.php\%3FFNAME\%3D1418718194.upl\%26ANAME\%3DAnal\%25C3\%25BDza\%2Bslovens keho\%2Bmedialneho\%2Btrhu.pd$\mathrm{f}+\& \mathrm{~cd}=1 \& \mathrm{hl}=\mathrm{sk} \& \mathrm{ct}=\mathrm{clnk} \& \mathrm{gl}=\mathrm{sk}>[$

PZ. (2018). Výdavky do Internetovej reklamy v roku 2017 narástli. Najviac zadávatelia investovali do nativnej reklamy. [online]. 2018 [8.10.2018]. Available at: ttps://strategie.hnonline.sk/ marketing/1721790-vydavky-do-Internetovej-reklamy-v-roku-2017-narastli-najviac-zadavatelia-investovali-do-nativnej-reklamy

Trampota, T., \& Vojtěchojvská, M. (2010). Metody výzkumu médií. Portál. ISBN 978-80-7367-683-4. 
Vavrečka, V. \& Mezuláník, J. (2015). Digital marketing communication tools in the process of implementation of marketing strategy of the tourist area Jeseníky - East. In Marketing Identity - Digital Life part I., Trnava: FMK, ISBN 978-80-8105-779-3, pp. 374-388.

Vlačuha, R. \& Kotlár, J. \& Želonková, V. (2012). Prieskum o využívaní informačných a komunikačných technológií v domácnostiach za 1. štvrt'rok 2012. Štatistický úrad Slovenskej republiky. ISBN 978-80-8121-152-2.

Vlačuha, R. \& Kotlár, J. \& Želonková, V. (2017). Zist'ovanie o využívaní informačných a komunikačných technológií v domácnostiach. Štatistický úrad Slovenskej republiky. ISBN 978-80-8121-571-1 (online) 